\title{
Effect of Massage Therapy in Cancer Patients
}

\author{
Marcia Alves ${ }^{1,2}$, Maria Helena de Agrela Gonçalves Jardim³ ${ }^{3}$ Bárbara Pereira Gomes ${ }^{4}$ \\ ${ }^{1}$ Biomedical Scientific Institute Abel Salazar, Porto, Portugal \\ ${ }^{2}$ Hospital Dr. Nélio Mendonça, Funchal, Portugal \\ ${ }^{3}$ Madeira University, Funchal, Portugal \\ ${ }^{4}$ School of Nursing of the Porto, Porto, Portugal \\ Email: *marcialves96@hotmail.com
}

How to cite this paper: Alves, M., de Agrela Gonçalves Jardim, M.H. and Gomes, B.P. (2017) Effect of Massage Therapy in Cancer Patients. International Journal of Clinical Medicine, 8, 111-121.

https://doi.org/10.4236/ijcm.2017.82010

Received: September 8, 2016

Accepted: February 20, 2017

Published: February 23, 2017

Copyright $\odot 2017$ by authors and Scientific Research Publishing Inc. This work is licensed under the Creative Commons Attribution International License (CC BY 4.0).

http://creativecommons.org/licenses/by/4.0/

\begin{abstract}
The increase in longevity and incidence of chronic diseases reveals an increased importance in terms of public health. The oncologic illness is a debilitating and progressive pathology with need for prevention and symptomatic relief. In order to find the answer to the question: "What is the effect of massage therapy in cancer patients?" we have reviewed the empirical literature indexed in databases online, finding only 21 articles published between 1990 and 2015. It was possible to verify some of the effects of massage therapy, particularly in relieving pain, decreased anxiety, depression and nausea and increased well-being. However, it was not found the effect of this intervention on the relief of suffering and the quality of life of patients. With the heterogeneity of methodologies, studies suggest the development of more homogeneous research, materials and methods to assess the effects of massage therapy in cancer patients.
\end{abstract}

\section{Keywords}

Patients, Oncology, Massage

\section{Introduction}

Massage therapy results in touch and its goals are varied including: the ability to help the body relax, feel pleasure to overcome physical problems, releasing emotional blocks, easing of pain, among others.

This type of massage is a method of treatment used in curing a disorder. The massage can be applied for therapeutic purposes, being able to assist in restoring the balance of the various human structures. It is assumed also that its application triggers mechanical effects, painkillers, psychological, structural and thermal effects, which are in line with the main purpose of our report.

According to [1] the purpose of the nurse is to interact with humans in situa- 
tions of health or disease, to improve the cultural and social context where they are inserted because they are suffering some kind of transition or anticipating the same. As for the nurse-patient interactions, these can be organized around a main purpose and the nurse uses some therapeutic actions to improve, bring or facilitate the patient's health.

In a second phase, with this report, we can analyse the effect of massage therapy on cancer patients. Being so, we have seen the number of patients with psychological changes increase, including depression, which decreases the quality of life of these patients and the depressive symptoms. This can actually generate a bigger limitation than the cancer itself and can cause suicide in about $50 \%$ of the patients. In turn, the anxiety has a prevalence rate of $18 \%-35.1 \%$ [2].

Among cancer patients, more than $70 \%$ suffer from pain caused by disease and/or by handling. Patients in advanced stages of cancer describe the pain as moderate or severe in approximately $40 \%$ to $50 \%$, and, according to [3] in $25 \%$ $30 \%$ of the patients. In 2004, the Hospice and Palliative Nurse Association has developed a document concerning the pain where it is quoted that this vital sign is one of the most feared by patients in end-of-life. Therefore, it is increased by the physiological stress and decreased by the morbidity, adding the risk of thromboembolism in these patients [4].

The skills of nurses can provide care to a patient in chronic condition aimed at caring for the person with the disease, lessening the suffering, maximizing their well-being, comfort and quality of life [5].

Nurses are crucial elements of a multidisciplinary team as nurses are actively involved in monitoring and pain relief, which requires the screening of the psychological, cognitive and emotional components of pain, including anxiety, depression and grief. Nurses also have previous experience in dealing with the pain, lack a personal, cultural and spiritual influence and can advise the prescription of non-pharmacological interventions in complementarity but not in replacement of pharmacological therapy, knowing their indications, contraindications and side effects [6] [7].

The massage can be curative and preventive, as it can rehabilitate and relief of muscle tension. Patients who benefit from these interventions exhibit lower levels of anxiety and pain, having more control over treatment decisions [8].

Based on the assumption that massage is beneficial to improve the patient's health condition, this literature review has found answers for the question "what is the effect of massage therapy on cancer patients?". Being so, the conclusion is that the purpose of the analysis conducted in this topic was achieved.

\section{Methodology}

This research was based on a systematic review of the literature with narrative summary. It was held exclusively in online databases, including EBSCO host (Medline, Cochrane Central Register of Controlled Trials, Cochrane Database of Systematic Reviews, Psychology and Behavioural Sciences Collection, EJS EJournals, British Nursing Index), SciELO and RCAAP (open access Scientific 
Repository of Portugal). As inclusion criteria we consider articles reported to the period between 1990 and 2015, in full-text, in English and Portuguese and about massage therapy in adult patients with medical diagnosis of cancer. The articles that didn't report the investigation around the theme under study and that did not present the predefined inclusion criteria were deleted.

The research resulted in 120 articles, being 50 articles on EBSCO host, 10 on Scielo and 60 in RCAAP, through the keywords for palliative care, oncology, cancer and massage therapy. Some articles had common databases and after full thorough reading, 21 studies were selected for systematic review. The remaining articles have been removed for not meeting the inclusion criteria (Figure 1).

For an analysis and synthesis of selected articles, it was created a summary table, contemplating various information extracted from each article and then a descriptive analysis of the results.

\section{Results}

The synopsis of the articles (Table 1) and selected studies are described under paragraph 1, in accordance with the year of publication, study goals, type of study, methods, and results. In relation to the year of publication, it was identified the prevalence of studies published in 2004, 2007 and 2008, with 3 articles each. 2 articles were published in the years 2000, 2003, and 2009, and the rest only obtained a publication for each date mentioned. It was observed that the intervention of massage therapy in oncology nursing professionals offers a limited number of researches, although with some concern over the past fifteen years. Methodologically, it was found that the majority of studies are the quantitative paradigm. The most commonly data collection instruments used was the Visual analogue scale (EVA) for the assessment of symptoms, including pain, anxiety and nausea. It was also observed the use of scale Brief Pain Index (BPI) for the assessment of pain and State-Trait Anxiety Inventory (STAI) for evaluation of anxiety. Only one article used mixed qualitative and quantitative methodology, combining the EVA and the interview as methods. Through the

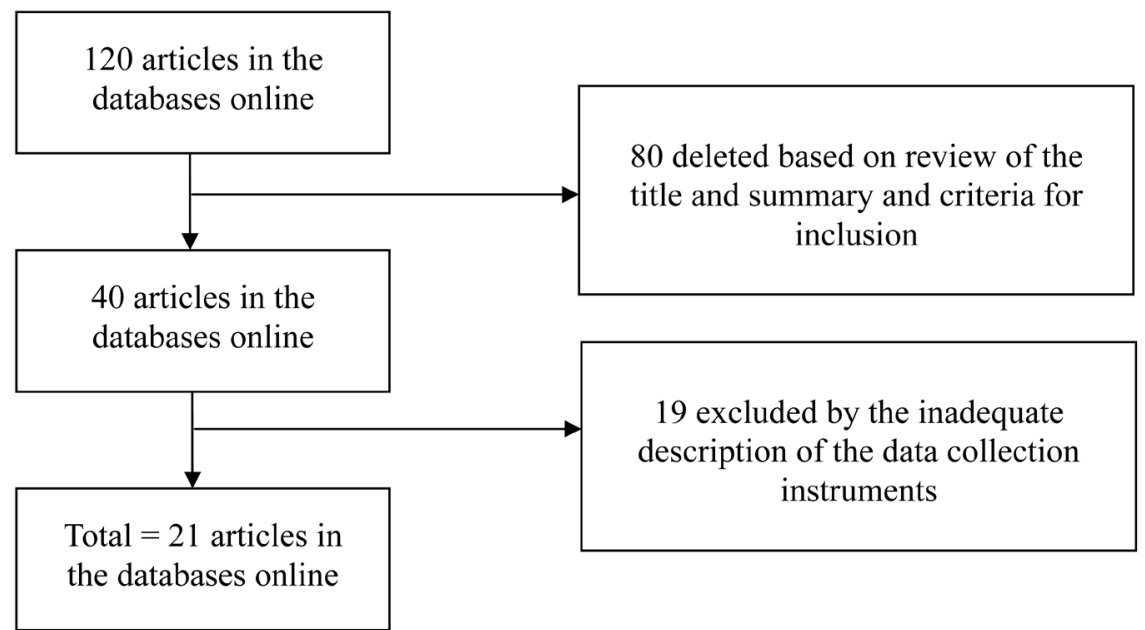

Figure 1. Reduction scheme. 
Table 1. General characterization of the articles reviewed.

\begin{tabular}{|c|c|c|c|c|c|c|}
\hline Author(s) & Date & Goal of the study & Type of study & Methods & Sample & Results \\
\hline $\begin{array}{l}\text { Weinrich, S, \& } \\
\text { Weinrich, M. }\end{array}$ & 1990 & $\begin{array}{l}\text { Evaluate the effect } \\
\text { of therapeutic massage } \\
\text { in the levels of pain }\end{array}$ & Experimental & $\begin{array}{l}\text { Visual Analogue Scale } \\
\text { (EVA). }\end{array}$ & $\begin{array}{l}28 \text { cancer } \\
\text { patients }\end{array}$ & $\begin{array}{l}\text {-Decrease of immediate } \\
\text { pain levels in males } \\
\text { and only in the } \\
\text { experimental group }\end{array}$ \\
\hline $\begin{array}{l}\text { Ferrell-Torry, } \\
\text { A., \& Glick, O. }\end{array}$ & 1993 & $\begin{array}{l}\text { Evaluate the } \\
\text { effectiveness of } \\
\text { therapeutic massage } \\
\text { in pain, anxiety, vital } \\
\text { signs and relaxation }\end{array}$ & Exploratory & $\begin{array}{l}\text { analogue for pain; } \\
\text {-Spielberger State } \\
\text { Anxiety Inventory; } \\
\text {-TA, FC, FR }\end{array}$ & $\begin{array}{l}9 \text { cancer } \\
\text { patients }\end{array}$ & $\begin{array}{l}\text {-Reduction of pain in } \\
60 \% \text { and anxiety } \mathrm{X}=24 ; \\
\text {-Reduction of vital signs, } \\
\text { indicating its } \\
\text { relaxing action }\end{array}$ \\
\hline $\begin{array}{l}\text { Ahles, T., Tope, } \\
\text { D., Pinkson, } \\
\text { B., Walch, S., Hann, } \\
\text { D., Whedon, M. }\end{array}$ & 1999 & $\begin{array}{l}\text { Analyze the impact of } \\
\text { therapeutic massage } \\
\text { in psychological, } \\
\text { physical and } \\
\text { Psychophysiological } \\
\text { measures }\end{array}$ & Experimental & $\begin{array}{l}\text { State-Trait Anxiety } \\
\text { Inventory (STAI), Beck } \\
\text { Depression Inventory } \\
\text { (BDI), and Brief Profile } \\
\text { of Mood States (POMS) }\end{array}$ & $\begin{array}{l}34 \text { patients } \\
\text { awaiting bone } \\
\text { marrow } \\
\text { transplant }\end{array}$ & $\begin{array}{l}\text { It Had immediate effect } \\
\text { on stress reduction, } \\
\text { nausea and anxiety } \\
\text { No significant difference } \\
\text { of these variables } \\
\text { in the long run }\end{array}$ \\
\hline $\begin{array}{l}\text { Wilkie, D., } \\
\text { Kampbell, J., } \\
\text { Cutshall, S., } \\
\text { Halabisky, H., } \\
\text { Harmon, H., } \\
\text { Johnson, L., et al. }\end{array}$ & 2000 & $\begin{array}{l}\text { Evaluate the effect of } \\
\text { therapeutic massage in } \\
\text { the levels of pain }\end{array}$ & Random study & EVA & $\begin{array}{l}29 \text { cancer } \\
\text { patients }\end{array}$ & $\begin{array}{l}\text {-Decrease in pain intensity } \\
\text { at } 42 \% \text { in the experimental } \\
\text { group and } 25 \% \text { for the con- } \\
\text { trol group }\end{array}$ \\
\hline $\begin{array}{l}\text { Grealish, L., } \\
\text { Lomasney, A., } \\
\text { \& Whiteman, B. }\end{array}$ & 2000 & $\begin{array}{l}\text { Analyze the impact } \\
\text { of massage therapy } \\
\text { in pain, nausea } \\
\text { and relaxation }\end{array}$ & Randomized & EVA. & $\begin{array}{l}87 \text { cancer } \\
\text { patients }\end{array}$ & $\begin{array}{l}\text {-Immediate Reduction of } \\
\text { pain, nausea and relaxation }\end{array}$ \\
\hline $\begin{array}{l}\text { Toth, M., Kahn, J., } \\
\text { Walton, T., Hrbek, } \\
\text { A., Eisenberg, D., } \\
\text { \& Russell, P. }\end{array}$ & 2003 & $\begin{array}{l}\text { Evaluate the effect } \\
\text { of massage therapy } \\
\text { in pain and anxiety }\end{array}$ & Pilot study & $\begin{array}{l}\text { Pain, anxiety (VAS) } \\
\text { and quality of } \\
\text { life (QOL) }\end{array}$ & $\begin{array}{l}26 \text { cancer } \\
\text { patients with } \\
\text { metastases }\end{array}$ & $\begin{array}{l}\text {-Decreased pain of } \\
5.50 \text { to } 3.83 \\
\text {-Increasing the anxiety } \\
\text { of } 3.83 \text { to } 4.75\end{array}$ \\
\hline $\begin{array}{l}\text { Post-White, } \\
\text { J., Kinney, } \\
\text { M. E., Savik, K., } \\
\text { Gau, J. B., Wilcox, } \\
\text { C., \& Lerner, I. }\end{array}$ & 2003 & $\begin{array}{l}\text { Determine whether } \\
\text { the therapeutic } \\
\text { massage and touch } \\
\text { are more effective } \\
\text { than the standard } \\
\text { treatment in reducing } \\
\text { symptoms of anxiety, } \\
\text { mood disorders, pain, } \\
\text { nausea and fatigue } \\
\text { and increasing relaxation } \\
\text { and satisfaction }\end{array}$ & Randomized & $\begin{array}{l}\text { BPI (Brief Pain Index); } \\
\text { BNI (Brief Nausea } \\
\text { Index); POMS } \\
\text { (Profile of Mood States) }\end{array}$ & 164 patients & $\begin{array}{l}\text {-Reduced levels of } \\
\text { anxiety, pain with } \\
\text { decreased use of pain } \\
\text { relievers, blood pressure, } \\
\text { heart rate and breathing }\end{array}$ \\
\hline $\begin{array}{c}\text { Soden, K., } \\
\text { Vincent, K., \& } \\
\text { Craske, S. }\end{array}$ & 2004 & $\begin{array}{l}\text { Evaluate the } \\
\text { effectiveness of the } \\
\text { massage to decrease } \\
\text { pain, anxiety, } \\
\text { depression, sleep } \\
\text { pattern and improve } \\
\text { the quality of life }\end{array}$ & Randomized & $\begin{array}{c}\text { EVA, Verran and } \\
\text { Snyder-Halpern (VSH) } \\
\text { (scale of sleep), hospital } \\
\text { anxiety and depression } \\
\text { scale (HAD) and the } \\
\text { list of Symptoms } \\
\text { Rotterdam (RSCL). }\end{array}$ & $\begin{array}{l}42 \text { cancer } \\
\text { patients }\end{array}$ & $\begin{array}{l}\text { No significant differences } \\
\text { in terms of improvement } \\
\text { in pain management, } \\
\text { anxiety or quality of life. } \\
\text {-Improved sleeping } \\
\text { patterns } \\
\text {-Reduction of depression } \\
\text { in the massage group }\end{array}$ \\
\hline $\begin{array}{l}\text { Hernandez-Reif, } \\
\text { M., Ironson, } \\
\text { G., Field, T., Hurley, } \\
\text { J., Katz, G., } \\
\text { \& Diego, M. }\end{array}$ & 2004 & $\begin{array}{l}\text { Evaluate the effect of } \\
\text { massage therapy in } \\
\text { anxiety, mood swings } \\
\text { and depression. }\end{array}$ & Experimental & $\begin{array}{l}\text { State Trait Anxiety } \\
\text { Inventory (STAI); } \\
\text { Profile of Mood } \\
\text { States (POMS); } \\
\text { symptom } \\
\text { Checklist-90-R } \\
\text { (SCL-90-R) }\end{array}$ & $\begin{array}{l}34 \text { women } \\
\text { with breast } \\
\text { cancer }\end{array}$ & $\begin{array}{l}\text {-Minimization in anxiety, } \\
\text { depressed mood and } \\
\text { anger in the short term; } \\
\text {-Minimization, } \\
\text { long-term, depression }\end{array}$ \\
\hline
\end{tabular}




\section{Continued}

Cassileth, B., \&

Vickers, A.
Evaluate the effect

of massage therapy

in pain, fatigue,

stress/anxiety,

nausea and

depression.

Deng, G., \&

Cassileth, B.

2005

Evaluate the effect of massage therapy in the relief of symptoms

Evaluate the effects of

Ferreira, A., \&

Lauretti, G.

2007

therapeutic massage in the control of pain

Wilkinson, S.,

Love, S.,

Wesrcombe,

A., Gambles,

M., Burgess,

C., Cargill, A.,

et al.

Billhut, A.,

Bergbom, I., \&

Stenes-Victorin, E.

Kutner, S., Smith,

M., Corbin, L.

Kemphill, 1.,

Benton, K., \&

Mellis, K.

Currin, J.;

Meister. E. massage therapy in pain, physical and emotional desnconforto and fatigue

therapeutic massage

in improving the

quality of life, pain,

stress, suffering

Analyze the impact of

randomized

Memorial Pain

Assessment Card; Brief Pain

Inventory [BPI];

McGill Quality of

Life Questionnaire;

Memorial Symptom

Assessment Scale

Young, C.

Experimental

-Reduction of pain, fatigue, stress, anxiety, nausea and depression

1290 cancer approximately 50\%

patients and in the same clinic improved $10 \%$ more than in the relocation and more durability.

-Decrease in the incidence of muscle fatigue, anxiety, 230 cancer depression, rescue patients analgesic consumption and improved circulatory and respiratory pattern.

34 cancer -Decrease in morphine

-There were no significant differences in improvement of anxiety and depression; 288 cancer -The anxiety improved patients self-report for patients who received massage therapy. This relationship did not exist for the self-report of depression.

-Significant Reduction

39 women of nausea in the with breast experimental group; cancer doing -There was no differences chemotherapy between anxiety and depression in both groups.

-Immediate improvements in mood and in pain, with more relevance in the experimental group.

380 advanced -In the long term there cancer was no statistical patients differences corroborate the improvement in quality of life, pain, stress, suffering and in decreasing the use of painkillers.

251 cancer patients

28 terminal cancer
-Decrease of pain, discomfort, emotional and physical fatigue.

-Decreased pain and depression for the experimental group. 


\section{Continued}

\begin{tabular}{|c|c|c|c|c|c|c|}
\hline $\begin{array}{l}\text { Downey, L., Diehr, P., } \\
\text { Standish, L., } \\
\text { Patrick, D., Kozak, L., } \\
\text { Fisher, D., et al. }\end{array}$ & 2009 & $\begin{array}{l}\text { Evaluate the effect of } \\
\text { massage therapy on } \\
\text { quality of life and pain }\end{array}$ & Randomized & $\begin{array}{c}\text { MSAS } \\
\text { (Memorial Symptom } \\
\text { Assessment Scale) }\end{array}$ & $\begin{array}{c}167 \\
\text { patients }\end{array}$ & $\begin{array}{l}\text {-Reduction of pain, } \\
\text { however, was not } \\
\text { statistically significant }\end{array}$ \\
\hline $\begin{array}{l}\text { Jane, S. W., Wilkie, } \\
\text { D. J., Gallucci, } \\
\text { B. B., Beaton, R. D., } \\
\text { \& Huang, H. Y. }\end{array}$ & 2009 & $\begin{array}{l}\text { Evaluate the } \\
\text { effectiveness of } \\
\text { massage in reducing } \\
\text { the levels of pain }\end{array}$ & $\begin{array}{c}\text { Quasi- } \\
\text { experimental }\end{array}$ & $\begin{array}{c}\text { VAS (anxiety) } \\
\text { MSF_MPQ } \\
\text { (Short-Form Mc-Grill } \\
\text { Pain Questionnaire): } \\
\text { BPI (Brief Pain } \\
\text { Inventory) }\end{array}$ & $\begin{array}{l}\text { Patients } \\
\text { with } \\
\text { metastases } \\
\text { bone }\end{array}$ & $\begin{array}{l}\text { Immediate effect } p=0.001 \\
\text { Medium effect } p<0.000 \\
\text { Long effect } p=0.04\end{array}$ \\
\hline $\begin{array}{l}\text { Adams, R., White, } \\
\text { B., \& Beckett, C. }\end{array}$ & 2010 & $\begin{array}{l}\text { Evaluate the effect } \\
\text { of massage therapy } \\
\text { in the levels of pain }\end{array}$ & $\begin{array}{l}\text { Qualitative } \\
\text { and } \\
\text { quantitative }\end{array}$ & $\begin{array}{c}\text { EVA } \\
\text {-interview }\end{array}$ & $\begin{array}{l}53 \text { cancer } \\
\text { patients }\end{array}$ & $\begin{array}{l}\text {-The pain level decreases } \\
\text { from } 5.18 \text { to } 2.33 \text { after the } \\
\text { intervention of the massage. } \\
\text {-Through the qualitative } \\
\text { data describe these } \\
\text { illustrate relevant } \\
\text { improvements in terms } \\
\text { of total pain, emotional } \\
\text { well-being, relaxation } \\
\text { and sleep patterns. }\end{array}$ \\
\hline $\begin{array}{l}\text { Sui-Whi, J., Wilkie, } \\
\text { D., Gallucci, } \\
\text { B., Beaton, R., } \\
\text { \& Huang, H.-Y. }\end{array}$ & 2011 & $\begin{array}{l}\text { Evaluate the } \\
\text { effectiveness of the } \\
\text { massage of pain, } \\
\text { anxiety and vital signs }\end{array}$ & Randomized & $\begin{array}{l}\text { (BPI-VAS) pain, } \\
\text { anxiety, sleep, } \\
\text { relaxation and } \\
\text { distress used VAS }\end{array}$ & $\begin{array}{l}36 \text { patients } \\
\text { with } \\
\text { metastases } \\
\text { bone }\end{array}$ & $\begin{array}{l}\text { Effective in the short and } \\
\text { in the long term with } \\
\text { regard to pain and anxiety, } \\
\text { There were no significant } \\
\text { effects that could } \\
\text { corroborate the changes } \\
\text { in heart rate and mean } \\
\text { arterial pressure. }\end{array}$ \\
\hline
\end{tabular}

analysis of the results of the studies selected, we categorized them according to the focus of nursing-(Classificação Internacional para a Prática de Enfermagem-CIPE), including pain, anxiety, depression, discomfort and suffering.

Taking into account the main results, it can be enhanced that massage therapy reduces: immediate levels of pain in male cancer patients [9], pain levels of approximately $50 \%$ plus an improvement of $10 \%$ in sick bay rather than in the relocation and more durability of such reduction in pain [10], the intensity of the pain between $60 \%$ [11] and $42 \%$ [12], as well as its average decrease of 5.50 to 3.83 [13] and 5.18 to 2.33 values [14]. Also, through the qualitative results enhance improvements of total pain [14]. This procedure significantly reduces the levels of pain [15] [16] [17], either immediately [18] [19] [20]; short-term (20/30 minutes) and long term (16/18 hours) [20], although the most significant impact occurred in the first few minutes after the intervention [21]. It also showed a decrease in analgesics used and consumption of rescue analgesics [15] [22], although the consumption of morphine was held for 10 days Nevertheless, there was a reduction in levels of pain after the 5th day [23]. However, there is a study which does not have significant differences that confirm the decline in the use of painkillers [19] [23]. Likewise, it was not shown significant changes in the long term benefits of massage in terms of improvement and pain control [19] [23]. 
These results corroborate a study, that although there was a decrease of pain, the difference was not statistically significant [22].

As for anxiety, there was a decrease of anxiety with $24 \%$ [11] and $50 \%$ [10], however only a study anxiety increased from 3.83 to 4.75 [13]. Other studies showed a significant reduction in anxiety and depression after massage therapy [10] [15] [17] [21] [22] [24].

Massage therapy has immediate effect in reducing depression and anxiety and also long-term depression [24] [25]. However, there are studies in which there were no differences in short term between anxiety and depression [26] [27] or that there were no significant differences of depression and anxiety in the long term [27]. Another study confirms these results, noting that there were no significant differences in improvement of anxiety and depression, however, through structured interviews, the self-report of anxiety has improved for patients who received massage therapy. This relationship did not exist for the self-report [28].

As far as the other variables studied, the massage contributes for the immediate reduction of nausea [10] [18] [26] [27], although it was mentioned the non-existence of significant differences of this long-term variable [15] [26]. It was referred the reduction of blood pressure, heart rate and breathing, indicating the relaxing action of massage therapy [11] [15] [22]. The complement of this intervention increases the relaxation [11] [14] [18], because they have immediate effect in depressed mood and anger [19] [24]. This intervention significantly decreased the incidence of muscular fatigue [10] [16] [22], reduces stress [10] and significantly improves the level of emotional well-being, relaxation and sleep patterns). It adds a significant decrease in dimensions of suffering in pain, physical and emotional discomfort, as well as on fatigue after massage [16]. The quality of life significantly improves [23], but in the long term there was no statistically significant differences that could corroborate the improvement of quality of life, stress and suffering [19] [25].

\section{Discussion}

The results described above emphasize the current need to increase the empirical evidence as well as raise awareness of the benefits associated with this type of interventions that are carried out by nursing staff-therapeutic massage, focusing particularly on the level of patients with oncological pathology.

However, most studies in this systematic review, enhance the effect of massage therapy on decreasing levels of pain and the intensity of some outbreaks that cause discomfort such as: providing relaxation, pleasure, avoid physical problems, release emotional blocks, easing of pain. In this particular case, it is up to the nurse to try to reduce the pain, anxiety, depression and discomfort.

Regarding pain, it was found on the basis of the described studies above, that the results converge because massage therapy decreases pain levels in some very significantly [9]-[18] [20] [21] and in others not so much [19] [22] [23]. We also note that there is the possibility of certain studies support that massage therapy causes patients to reduce the use of painkillers and recourse to SOS [15] [22], 
however it was concluded that the differences are not that significant [19] [23].

In terms of anxiety and depression there were also contradictory results because some have revealed positive effects that patients feel in a short term [10] [15] [17] [21] [22] [24], other long-term [24] [25] and others did not reveal any effects [26] [27].

There are also discrepancies about the other areas of nursing, with respect to the effectiveness of massage therapy, the level of nausea, as some studies consider that massage therapy has benefits [10] [18] [26] [27] and others don't mention them [15] [26].

However, it was found that this intervention has obtained positive results, associated with decreased vital signs due to the relaxation promoted [11] [15] [22], in the depressed mood and anger [19] [24], on muscle fatigue [10] [16] [22], in stress [10] and the level of emotional well-being and sleep patterns [14] [25]. There was no statistical differences that could corroborate the improvement in quality of life, stress and suffering [19] [26], justifying the interest of this study.

\section{Conclusions}

Although the analysis of the results was in many cases contradictory, showing positive and negative or neutral data, the purpose of our study allowed us to conclude that massage therapy has beneficial effects. Being so, in a short term, the level of emotional well-being and relaxation increases, as physical and emotional discomfort, depressed mood, sleep patterns and stress decrease. The level of quality of life and suffering is contradictory, reporting to future investigations continuity perspective.

Through this study, we found the need to step up the research in the field of nursing, broadening the field of nurses, leading to effective therapeutic interventions carried out by these professionals so that we can control and lessen the anxiety and depression.

The nurse has an important role in the patients' recovery, highlighting their feelings and contributing to improve their self-esteem. In this sphere, the massage therapy intervention is essential, as the constant contact of the nurse with the patient encourages the implementation of these actions in order to relieve pain, promote common assistance and improve one's quality of life.

It was noted also that the use of massage therapy is a reality in the universe of human health, nurses increasingly resorting to this type of interventions that had been used for a long time for the patient's comfort. Our role as investigators and researchers is to establish scientifically the effects and benefits of this intervention, in order to add them to the non-pharmacological therapies that are already incorporated in the current health care system.

It is well known that even with the lack of research in this area, the nurses in their day-to-day work already use some therapies for pain control, such as relaxation techniques, cutaneous stimulation (massage, heat/cold, transcutaneous electrical stimulation), among others.

It was found that the relaxation promotes the reduction of these factors, especially the muscle tension, improving the pain, because muscle contraction con- 
tributes to exacerbation of pain, focusing on the nerve endings, especially in chronic pain.

With the preparation of this study, we realised that massage therapy decreases total pain levels, both in a short or long term, and that, according to some authors, decreased the use of analgesics and the consumption of painkillers.

It seems that with the implementation of the relaxation massage, it can actually help rebalancing the body. However, most complementary therapies, lead people to submit the relaxation response. Such techniques are related to existing interaction between pain, muscle tension and anxiety, because a patient with pain often presents feelings of apprehension and fear, leading to muscle tension which in turn worsens the pain.

It is important to note that the additional practices that can be used as nonpharmacological treatment of pain, are two groups: techniques or methods carried out by nurses in the nursing consultation and that require expertise or professional qualification.

The care factors depend on the humanistic expectation, associated with the scientific knowledge and concept of mutuality that should exist between the nurse and the patient. That is why the nursing staff have the duty to be aware of the patient' complaints. The body pain that is felt by the patient should always be monitored, so that his story is as improved and real as possible, regarding the evidence of pain and description of its intensity in order to have a combat intervention as efficient as possible.

One of the nurse's contributions is the emphasis on care practice as interpersonal, based on factors that result in the satisfaction of human needs, promoting health, as well as an individual and family growth. It is essential to understand the environment as favouring the personal development and integrated in the biophysical and human behavioural knowledge.

Finally, and still on the basis of the results obtained, we also suggest the development of more research in order to give greater consistency to empirical effects of massage intervention, cancer patients and so contributing to the practice of nursing excellence based on evidence.

\section{References}

[1] Afaf, A.M. (2012) Theoretical Nursing Development \& Progress. Wolters Kluwer, Philadelphia.

[2] Castro, E., Scorza, A. and Chem, C. (2011) Qualidade de vida e indicadores de ansiedade e depressão de pacientes com cancro colo-rectal. Psicologia, Saúde \& Doenças, 12, 131-142.

[3] Bair, M., Robinson, R., Katon, W. and Kroenke, K. (2003) Depression and Pain Comorbidity-A Literature Review. Archives of Internal Medicine, 163, 2433-2445. https://doi.org/10.1001/archinte.163.20.2433

[4] Runnig, A., Shreffler-Grant, J. and Andrews, W. (2008) A Survey of Hospices Use of Complementary. Journal of Hospice and Palliative Nursing, 10, 304-312. https://doi.org/10.1097/01.NJH.0000319177.25294.e5

[5] Ordem dos Enfermeiros (2011) Regulamento de competências especificas do enfer- 
meiro especialista em enfermagem em pessoa em situação crónica e paliativa. Ordem dos Enfermeiros, Portugal.

[6] Ordem dos Enfermeiros (2008) Dor Guia de Boas Práticas. Ordem dos Enfermeiros, Portugal.

[7] Direção Geral de Saúde (DGS) (2001) Plano Nacional de Luta Contra a Dor. Direção Geral de Saúde, Portugal, 60 p.

[8] Almeida, M.D. and Duarte, S.. (2000) Massagem dorsal de bem-estar e de conforto. Referência, 75-78.

[9] Weinrich, S. and Weinrich, M. (1990) The Effect of Massage on Pain in Cancer Patients. Applied Nursing Research, 3, 140-145. https://doi.org/10.1016/S0897-1897(05)80135-1

[10] Cassileth, B. and Vickers, A. (2004) Massage Therapy for Sympton Outcome Study at a Major Cancer Center. Journal Pain Sympton Manage, 28, 244-249. https://doi.org/10.1016/j.jpainsymman.2003.12.016

[11] Ferrell-Torry, A. and Glick, O. (1993) The Use of therapeutic Massage as a Nursing Intervention to Modify Anxiety and the Perception of Cancer Pain. Cancer Nursing, 16, 93-101. https://doi.org/10.1097/00002820-199304000-00002

[12] Wilkie, D., Kampbell, J., Cutshall, S., Halabisky, H., Harmon, H., Johnson, L., Rake-Marona, M., et al. (2000) Effects of Massage on Pain Intensity, Analgesics and Quality of Life in Patients with Cancer Pain: A Pilot Study of a Randomized Clinical Trial Conducted with Hospice Care Delivery. Hospice Journal: Physical, Psychosocial, \& Pastoral Care of the Dying, 15, 31-53. https://doi.org/10.1300/J011v15n03_03

[13] Toth, M., Kahn, J., Walton, T., Hrbek, A., Eisenberg, D. and Russell, P. (2003) Therapeutic Massage, Intervention for Hospitalized Patients with Cancer. Alternative \& Complementary Therapies, 9, 117-124. https://doi.org/10.1089/107628003322017341

[14] Adams, R., White, B. and Beckett, C. (2010) The Effects of Massage Therapy on Pain Management in the Acute Care Setting. International Journal of Therapeutic Massage \& Bodywork, 3, 4-11.

[15] Post-White, J., Kinney, M.E., Savik, K., Gau, J.B., Wilcox, C. and Lerner, I. (2003) Therapeutic Massage and Healing Touch Imporve Symptons in Cancer. Intergrative Cancer Therapies, 2, 332-344. https://doi.org/10.1177/1534735403259064

[16] Currin, J. and Meister, E. (2008) A Hospital-Based Intervention Using Massage to Reduce Distress among Oncology Patients. Cancer Nursing, 31, 214-221. https://doi.org/10.1097/01.NCC.0000305725.65345.f3

[17] Young, C. (2008) Effects of Aroma Hand Massage on Pain, State Anxiety and Depression in Hospice Patients with Terminal Cancer. Journal of Korean Academy of Nursing, 38, 493-502. https://doi.org/10.4040/jkan.2008.38.4.493

[18] Grealish, L., Lomasney, A. and Whiteman, B. (2000) Foot Massage: A Nursing Intervention to Modify the Distressing Symptoms of Pain and Nausea in Patients Hospitalized with Cancer. Cancer Nursing, 23, 237-243. https://doi.org/10.1097/00002820-200006000-00012

[19] Kutner, S., Smith, M., Corbin, L., Kemphill, 1., Benton, K. and Mellis, K. (2008) Massage Therapy versus Simple Touch to Improve and Mood in Patients with Advanced Cancer: A Randomized Trial. Annals of Internal Medicine, 149, 369-379. https://doi.org/10.7326/0003-4819-149-6-200809160-00003

[20] Sui-Whi, J., Wilkie, D., Gallucci, B., Beaton, R. and Huang, H.-Y. (2011) Effects of Massage on Pain, Mood Status, Relaxation, and Sleep in Taiwanese Patients with Metastasic Bone Pain. A Randomized Clinical Trial. Pain, 152, 2432-2442. 
https://doi.org/10.1016/j.pain.2011.06.021

[21] Jane, S.W., Wilkie, D.J., Gallucci, B.B., Beaton, R.D. and Huang, H.Y. (2009) Effects of a Full-Body Massage on Pain Intensity, Anxiety, and Physiological Relaxation in Taiwanesse Patients with Mestastasic Bone Pain: A Pilot Study. Journal of Pain Sympton Manage, 37, 754-763. https://doi.org/10.1016/j.jpainsymman.2008.04.021

[22] Deng, G. and Cassileth, B. (2005) Integrative Oncology: Complementary Therapies for Pain, Anxiety, and Mood Disturbance. Cancer Journal for Clinicians, 55, 109-116. https://doi.org/10.3322/canjclin.55.2.109

[23] Ferreira, A. and Lauretti, G. (2007) Estudo dos efeitos da massoterapia no alívio da dor e na melhoria da qualidade de vida em pacientes oncológicos sob cuidados paliativos. Revista Dor, 8, 983-993

[24] Hernandez-Reif, M., Ironson, G., Field, T., Hurley, J., Katz, G. and Diego, M. (2004) Breast Cancer Functions Following Massage Therapy. Journal of Psychosomatic Research, 57, 45-52. https://doi.org/10.1016/S0022-3999(03)00500-2

[25] Soden, K., Vincent, K. and Craske, S. (2004) A Randomized Controlled Trial of Aromatherapy Massage in a Hospice Setting. Palliative Medicine, 18, 87-92. https://doi.org/10.1191/0269216304pm874oa

[26] Ahles, T., Tope, D., Pinkson, B., Walch, S., Hann, D., Whedon, M. and Silberfarb, P. (1999) Massage Therapy for Patients Undergoing Autologous Bone Marrow Transplantation. Journal of Pain \& Sympton Management, 18, 157-163. https://doi.org/10.1016/S0885-3924(99)00061-5

[27] Billhut, A., Bergbom, I. and Stenes-Victorin, E. (2007) Massage Relieves Nausea in Women with Breast Cancer Who Are Undergoing Chemotherapy. Journal of Alternative and Complementary Medicine, 13, 53-57. https://doi.org/10.1089/acm.2006.6049

[28] Wilkinson, S., Love, S., Wesrcombe, A., Gambles, M., Burgess, C., Cargill, A., Ramirez, A., et al. (2007) Effectiveness of Aromatherapy Massage in the Management of Anxiety and Depression in Patients with Cancer. A Multicenter Randomized Controlled Trial. Journal of Clinical Oncology, 25, 532-538. https://doi.org/10.1200/JCO.2006.08.9987

Scientific Research Publishing

Submit or recommend next manuscript to SCIRP and we will provide best service for you:

Accepting pre-submission inquiries through Email, Facebook, LinkedIn, Twitter, etc. A wide selection of journals (inclusive of 9 subjects, more than 200 journals)

Providing 24-hour high-quality service

User-friendly online submission system

Fair and swift peer-review system

Efficient typesetting and proofreading procedure

Display of the result of downloads and visits, as well as the number of cited articles

Maximum dissemination of your research work

Submit your manuscript at: http://papersubmission.scirp.org/

Or contact ijcm@scirp.org 